\title{
Effect of Biofield Energy Treatment on Streptococcus group B: A Postpartum Pathogen
}

Mahendra Kumar Trivedi', Alice Branton'1, Dahryn Trivedi', Gopal Nayak', Harish Shettigar ${ }^{1}$, Sambhu Charan Mondal ${ }^{2}$ and Snehasis Jana ${ }^{2 *}$

${ }^{1}$ Trivedi Global Inc., 10624 S Eastern Avenue Suite A-969, Henderson, NV 89052, USA

${ }^{2}$ Trivedi Science Research Laboratory Pvt. Ltd., Hall-A, Chinar Mega Mall, Chinar Fortune City, Madhya Pradesh, India

\begin{abstract}
Streptococcus agalactiae group B (S. agalactiae gr. B) is widespread in nature mainly causes bacterial septicemia and neonatal meningitis. The current study was attempted to investigate the effect of biofield treatment on S. agalactiae gr. B with respect of antimicrobial sensitivity, biochemical reactions and bio typing. S. agalactiae gr. B strain was used in this experiment bearing the American Type Culture Collection (ATCC 12386) number and stored according to the recommended storage protocol. The revived and lyophilized state of ATCC strains of S. agalactiae gr. B were selected for the study. Gr. I was considered as control. Both revived (Group; Gr. II) and lyophilized (Gr. III) strains of S. agalactiae gr. B were subjected to Mr. Trivedi's biofield treatment. Gr. II was assessed on day 5 and day 10 while Gr. III on day 10 with respect to the control (Gr. I) using MicroScan Walk-Away ${ }^{\circledR}$ system. Although biofield treatment did not show any change with respect to susceptibility pattern. However the minimum inhibitory concentration of S. agalactiae gr. B showed significant $(70.37 \%)$ alteration, out of twenty-seven tested antimicrobials, among which in Gr. II i.e. $62.96 \%$ on day 5 and $66.67 \%$ on day 10 while no alteration was found in lyophilized group (Gr. III) as compared to the control. Moreover, the improvement of MIC value of norfloxacin was observed by two-fold ( 8 to $\leq 4 \mu \mathrm{g} / \mathrm{mL}$ ) in $\mathrm{Gr}$. II on day 10 after biofield energy treatment as compared to the control. It was observed that overall $48.28 \%$ biochemical reactions, out of twenty-nine were altered in $\mathrm{Gr}$. II with respect to the control. Moreover, biotype numbers were changed in Gr. II on day 5 (777777615) and on day 10 (757677405) as compared to the control (237147047). The results suggest that biofield treatment has significant impact on $S$. agalactiae gr. B in revived treated cells (Gr. II) with respect to MIC values, biochemical reactions pattern and biotype number.
\end{abstract}

Keywords: Streptococcus agalactiae group B; Biofield treatment; Minimum inhibitory concentration; Biochemical reaction; Biotype

Abbreviations: CLSI: Clinical and laboratory standards institute; GBS: Group B Streptococci; CAMP: Christie-Atkins-Munch-Petersen; CDC: Centers for Disease Control and Prevention; ACOG: American College of Obstetricians and Gynecologists; AAP: American Academy of Pediatrics; MIC: Minimum inhibitory concentration; ATCC: American Type Culture Collection; PBPC 20: Positive Breakpoint Combo 20

\section{Introduction}

Group B Streptococci (GBS), or Streptococcus agalactiae group B, are Gram-positive, non-spore forming, non-motile, $\beta$-hemolytic and chain-forming cocci bacteria. It is mainly inhabitant in human gut flora and female urogenital tract [1]. Pregnant women [2] and neonates [3] are the main victim host of this organism. It can be transferred to neonates through the birth canal and causes bacterial septicaemia and neonatal meningitis [4]. Most of GBS, produce Christie-Atkins-Munch-Petersen (CAMP) factor or protein B an extracellular cytolytic protein and $\beta$-lysin from Staphyllococcus species are jointly lysed the erythrocytes [5]. It is estimated that in US over 70,000 cases of GBS diseases were prevented [6]. Several antibiotics such as penicillin, ampicillin, amoxicillin, cephalosporins (all three generations), macrolides, clindamycin and vancomycin (as alternative) have been used to treat against GBS infections. Among above mentioned antibiotics penicillin is the drug of choice next to cefazolin. However, it also have certain limitations such as high minimum inhibitory concentration (MIC), a factor associated with high level of bacteremia and more concentration of microbes in tissue, especially in cerebrospinal fluid $[7,8]$. Therefore, some alternative treatment strategies are needed to overcome these lacunas against $\beta$-hemolytic strain of gr. B Streptococci. Biofield treatment has been known as an alternative approach that may be useful for S. agalactiae group B infected patients.

Researchers have shown that short-lived electrical events or action potential exist in the several type of mammalian cells such as neurons, muscles, and endocrine cells [9]. For instance, when the cells present in central nervous system of human body communicate with each another by means of electrical signals that propagate along the nerve impulses. Therefore, it was hypothesized that biofield exists around the human body and evidence was found using electromyography, electrocardiography and electroencephalogram [10]. Thus, the human body emits the electromagnetic waves in the form of bio-photons, which surrounds the body and it is commonly known as biofield. Therefore, the biofield consists of electromagnetic field, being generated by moving electrically charged particles (ions, cell, molecule etc.) inside the human body. Rivera-Ruiz reported that electrocardiography has been extensively used to measure the biofield of human body [11] Thus, human has the ability to harness the energy from environment or Universe and can transmit into any living or nonliving object(s) around the Globe. The objects always receive the energy and responding into useful way that is called biofield energy and the process is known as

*Corresponding author: Snehasis Jana, Trivedi Global Inc., 10624 S Eastern Avenue Suite A-969, Henderson, NV 89052, USA, Tel: +91-755-6660006; E-mail: publication@trivedisrl.com

Received August 12, 2015; Accepted September 01, 2015; Published September 08, 2015

Citation: Trivedi MK, Branton A, Trivedi D, Nayak G, Shettigar H, et al. (2015) Effect of Biofield Energy Treatment on Streptococcus group B: A Postpartum Pathogen. J Microb Biochem Technol 7: 269-273. doi:10.4172/1948-5948.1000223

Copyright: @ 2015 Trivedi MK, et al. This is an open-access article distributed under the terms of the Creative Commons Attribution License, which permits unrestricted use, distribution, and reproduction in any medium, provided the original author and source are credited. 
biofield treatment that is also called as Trivedi effect. Mr. Trivedi's unique biofield treatment has been known to transform the structural, physical, and thermal properties of several metals in material science [12-14], improved the overall productivity of crops [15,16], altered characteristics features of microbes [17-19] and improved growth and anatomical characteristics of various medicinal plants [20,21].

Due to the clinical significance of this organism and literature reports on biofield treatment, the present work was undertaken to evaluate the impact of biofield treatment on $S$. agalactiae group B in relation to antimicrobials susceptibility and bio typing based on various biochemical characters.

\section{Materials and Methods}

S. agalactiae group B, American Type Culture Collection (ATCC 12386) strains were procured from MicroBioLogics, Inc., USA, in two sets A and B. Two different sealed packs were stored with proper storage conditions until further use. All the tested antimicrobials and biochemicals were procured from Sigma-Aldrich, MA, USA. The antimicrobial susceptibility, biochemical reactions and biotype number were estimated with the help of MicroScan Walk-Away' (Dade Behring Inc., West Sacramento, CA, USA) using Positive Breakpoint Combo 20 (PBPC 20) panel with respect to the control group.

\section{Experimental design}

Two ATCC samples A and B of S. agalactiae gr. B were grouped (Gr.). ATCC A sample was revived and divided into two parts Gr.I (control) and Gr.II (revived); likewise, ATCC B was labeled as Gr.III (lyophilized).

\section{Biofield treatment strategy}

The Gr. I remained as untreated. The treatment Gr. II and III in sealed pack were handed over to Mr. Trivedi for biofield energy treatment under laboratory condition. Mr. Trivedi provided the treatment through his energy transmission process which includes bioenergy emission to the treated groups (Gr. II and Gr. III) without touching the samples. After treatment, sample was handed over in the same condition and stored at standard conditions as per the standard experimental protocol. An optimum precautionary measure were taken while evaluating the study parameters throughout the experiments. The differences in parameters before and after the treatment were noted and compared. Gr.II was assessed at two time point i.e. on day 5 and day 10, while Gr. III was assessed on day 10 for antimicrobial susceptibility, MIC, biochemical reactions pattern, and biotyping.

\section{Antimicrobial susceptibility test}

Investigation of antimicrobial susceptibility of S. agalactiae gr. B was carried out with the help of automated instrument, MicroScan Walk-Away system using PBPC 20 panel as per the clinical and laboratory standards institute (CLSI) guidelines. The test was carried out on MicroScan, which was miniaturized of the broth dilution susceptibility test that has been dehydrated. Briefly, the standardized suspension of $S$. agalactiae gr. B was inoculated, rehydrated, and then subjected to incubation for 16 hours at $35^{\circ} \mathrm{C}$. The detailed experimental procedures and conditions were followed as per the manufacturer's instructions. The antimicrobial susceptibility pattern and MIC were determined by observing the lowest antimicrobial concentration showing growth inhibition [22].

\section{Biochemical reaction studies}

Biochemical reactions of $S$. agalactiae gr. B were determined using MicroScan Walk-Away, system with PBPC 20 panel [22]. Biochemicals used in the study were arabinose, arginine, bacillosamine, bile esculin, $\beta$-lactamases, crystal violet, hemolysin, indoxyl phosphatase, inulin, acidification lactose, mannitol, mannose, micrococcus screen, sodium chloride, nitrate, novobiocin, optochin, $p$-nitro phenyl $\beta$-Dglucuronide, $p$-nitro phenyl $\beta$-D-galactopyranoside, phosphatase, pyruvate, pyrolidonyl arylamidase, raffinose, rambose, sorbitol, thymidine free growth, acidification trehalose, urea, and VogesProskauer.

\section{Identification of organism by biotype number}

The biotype number of $S$. agalactiae gr. B was determined on MicroScan Walk-Away processed panel data report with the help of biochemical reactions data [22].

\section{Results and Discussion}

\section{Antimicrobial susceptibility test}

The outcomes of MIC values of tested antimicrobials against $S$. agalactiae gr. B after biofield treatment are summarized in Table 1 . The data were analyzed using automated system and compared with respect to the control. In this experiment, twelve antibiotics were used to investigate the susceptibility pattern on GBS viz. ampicillin, cefepime, cefotaxime, ceftriaxone, chloramphenicol, clindamycin, levofloxacin, linezolid, ofloxacin, penicillin, tetracycline, and vancomycin. Out of these, five antibiotics showed susceptible in the control sample. It has been evidenced from literatures that penicillin and its derivatives are the choice of drugs against gr. B streptococcal infection $[8,9]$. However, biofield treatment did not show any alteration with respect to susceptibility pattern in all the treated groups after biofield treatment (data not shown). Besides sensitivity assay, the MIC values of tested antimicrobials were significantly $(70.37 \%)$ altered out of twenty seven as compared to the control. The MIC value of norfloxacin was reduced by two-fold to $\leq 4 \mu \mathrm{g} / \mathrm{mL}$ after biofield treatment in $\mathrm{Gr}$. II on day 10 as compared to the control $(8 \mu \mathrm{g} / \mathrm{mL})$. The MIC values of cefazolin, cephalothin, and chloramphenicol were changed from $\leq 8$ to $>16 \mu \mathrm{g} /$ $\mathrm{mL}$ in Gr. II on day 5 and 10 as compared to the control. The MIC values of rifampin and synercid were changed from $\leq 1$ to $>2 \mu \mathrm{g} / \mathrm{mL}$ in Gr. II on day 5 and 10 as compared to the control. Alteration of MIC values of cefotaxime and ceftriaxone were changed from $\leq 8$ to $32 \mu \mathrm{g} / \mathrm{mL}$ in $\mathrm{Gr}$. II on day 5 and 10 as compared to the control. Moreover, MIC values of amoxicillin/k-clavulanate and trimethoprim/sulfamethoxazole were slightly changed from $\leq 4 / 2$ to $>4 / 2 \mu \mathrm{g} / \mathrm{mL}$ (on day 5 and 10 ) and $\leq 2 / 38$ to $>2 / 38 \mu \mathrm{g} / \mathrm{mL}$ (on day 5 ) respectively in Gr. II after biofield treatment as compared to the control. Antimicrobial linezolid showed an alteration of MIC value in Gr. II on day $5(>4 \mu \mathrm{g} / \mathrm{mL})$ and on day $10(4 \mu \mathrm{g} / \mathrm{mL})$ as compared to the control. Besides this, alteration of MIC values were observed in case of penicillin $(\leq 0.03$ to $>8 \mu \mathrm{g} / \mathrm{mL})$, vancomycin $(\leq 0.2$ to $>16 \mu \mathrm{g} / \mathrm{mL})$, nitrofurantoin $(\leq 32$ to $>64 \mu \mathrm{g} / \mathrm{mL})$, clindamycin ( $\leq 0.5$ to $>2 \mu \mathrm{g} / \mathrm{mL})$, ampicillin $(\leq 0.25$ to $>8 \mu \mathrm{g} / \mathrm{mL})$ and ampicillin/sulbactam $(\leq 8 / 4$ to $>16 / 8 \mu \mathrm{g} / \mathrm{mL})$ in Gr. II on day 5 and 10 as compared to the control. The MIC value of tetracycline was changed from $\leq 4$ to $8 \mu \mathrm{g} / \mathrm{mL}$ in $\mathrm{Gr}$. II on day 10 and MIC value of oxacillin was changed from $\leq 0.25$ to $>2 \mu \mathrm{g} / \mathrm{mL}$ (on day 5 ) and $2 \mu \mathrm{g} / \mathrm{mL}$ on day 10 in Gr. II as compared to control. Antimicrobials did not show any change in MIC value in Gr. III as compared to the control after biofield treatment. Seventeen out of twenty seven (62.96\%) antimicrobials showed alteration of MIC value in Gr. II on day 5 and 66.67\% (eighteen 
out of twenty seven) on day 10 as compared to the control after biofield treatment. Eight, out of twenty seven tested antimicrobials (29.63\%) viz. cefepime, ciprofloxacin, gatifloxacin, imipenem, levofloxacin, moxifloxacin, ofloxacin and piperacillin/tazobactam did not show any alteration of MIC values in all the treated cells of GBS as compared to the control (Table 1).

\section{Biochemical reactions studies}

Study of biochemical reactions can be utilized to identify the enzymatic and metabolic characteristic features of microbes. Microorganisms can be categorically differentiated based on their utilization of specific biochemicals as nutrients during the process of metabolism or enzymatic reactions. The specific biochemical showed some changes against $S$. agalactiae gr. B after biofield treatment that are shown in Table 2. Biochemicals such as bile esculin (BE), crystal violet $(\mathrm{CV})$, mannitol (MAN), sodium chloride $(\mathrm{NaCl})$, nitrate (NIT), novobiocin (NOV), pyrolidonyl arylamidase (PYR) and urea (URE) were changed from negative $(-)$ to positive $(+)$ reactions in revived treated group (Gr. II) on day 5 and 10, but remained same i.e. negative (-) reaction in lyophilized treated cells (Gr. III) with respective to control. Arginine (ARG) and glycosidase (PGR) were converted from positive (+) to negative (-) reactions in Gr. II on day 10, while remained unchanged i.e. positive (+) on day 5 in Gr. II and in Gr. III as compared to the control in biofield treated S. agalactiae gr. B. Similarly, pyruvate (PRV), and rambose (RBS) were converted from positive $(+)$ to negative (-) reactions on both days in Gr. II, while did not show any change in Gr. III as compared with the control. Moreover, biochemicals such as raffinose (RAF) and sorbitol (SOR) showed an alteration of biochemical reaction i.e. negative (-) to positive (+) in Gr. II on day 5 while remained negative in Gr. II on day 10 and in Gr. III as compared to the control.

The one of the key characteristic feature for GBS is complete lysis of red blood cells and metabolization of sugars by fermentation process. Hence, in control sample the positive reaction of hemolysin (HEM) indicated $\beta$-hemolysis of erythrocytes and positive reaction of acidifying lactose (LAC) indicated the production of lactic acid as biproduct. The data was supported with literature [23]. Similarly, based on existing literature pyrolidonyl arylamidase (PYR) has negative reaction in group B streptococcal species while positive reaction in group A streptococcal. Control data of PYR was well supported with literature data [24]. However, after biofield treatment the negative reaction was altered in Gr. II, assessed on day 5 as well as day 10 due to change of enzymatic reaction.

Overall, $48.28 \%$ biochemical reactions were altered in tested twenty-nine biochemicals with respect to the control after biofield treatment. In both time points of Gr. II (day 5 and 10) 41.38\% (twelve out of twenty-nine) biochemical reactions were altered as compared to the control. About $51.72 \%$ out of twenty-nine biochemicals, such as arabinose (ARA), bacillosamine (BAC), $\beta$-lactamase (BL), hemolysin (HEM), indoxyl phosphatase (IDX), inulin (INU), acidification lactose (LAC), mannose (MNS), micrococcus screen (MS), optochin (OPT), glycosidase (PGT), phosphatase (PHO), thymidine free growth (TFG), acidification trehalose (TRE), and Voges-Proskauer (VP) did not

\begin{tabular}{|c|c|c|c|c|c|}
\hline \multirow[t]{3}{*}{ S. No. } & \multirow[t]{3}{*}{ Antimicrobial } & \multicolumn{4}{|c|}{ Type of Response } \\
\hline & & \multirow[t]{2}{*}{ Gr. I } & \multicolumn{2}{|c|}{ Gr. II } & \multirow[t]{2}{*}{ Gr. III } \\
\hline & & & Day 5 & Day 10 & \\
\hline 1. & Amoxicillin/k-clavulanate & $\leq 4 / 2$ & $>4 / 2$ & $>4 / 2$ & $\leq 4 / 2$ \\
\hline 2. & Ampicillin/sulbactam & $\leq 8 / 4$ & $>16 / 8$ & $>16 / 8$ & $\leq 8 / 4$ \\
\hline 3. & Ampicillin & $\leq 0.25$ & $>8$ & $>8$ & $\leq 0.25$ \\
\hline 4. & Cefazolin & $\leq 8$ & $>16$ & $>16$ & $\leq 8$ \\
\hline 5. & Cefepime & $\leq 8$ & $\leq 8$ & $\leq 8$ & $\leq 8$ \\
\hline 6. & Cefotaxime & $\leq 8$ & 32 & 32 & $\leq 8$ \\
\hline 7. & Ceftriaxone & $\leq 8$ & 32 & 32 & $\leq 8$ \\
\hline 8. & Cephalothin & $\leq 8$ & $>16$ & $>16$ & $\leq 8$ \\
\hline 9. & Chloramphenicol & $\leq 8$ & $>16$ & $>16$ & $\leq 8$ \\
\hline 10. & Ciprofloxacin & $\leq 1$ & $\leq 1$ & $\leq 1$ & $\leq 1$ \\
\hline 11. & Clindamycin & $\leq 0.5$ & $>2$ & $>2$ & $\leq 0.5$ \\
\hline 12. & Gatifloxacin & $\leq 2$ & $\leq 2$ & $\leq 2$ & $\leq 2$ \\
\hline 13. & Imipenem & $\leq 4$ & $\leq 4$ & $\leq 4$ & $\leq 4$ \\
\hline 14. & Levofloxacin & $\leq 2$ & $\leq 2$ & $\leq 2$ & $\leq 2$ \\
\hline 15. & Linezolid & $\leq 2$ & $>4$ & 4 & $\leq 2$ \\
\hline 16. & Moxifloxacin & $\leq 2$ & $\leq 2$ & $\leq 2$ & $\leq 2$ \\
\hline 17. & Nitrofurantoin & $\leq 32$ & $>64$ & $>64$ & $\leq 32$ \\
\hline 18. & Norfloxacin & 8 & 8 & $\leq 4$ & 8 \\
\hline 19. & Ofloxacin & $\leq 2$ & $\leq 2$ & $\leq 2$ & $\leq 2$ \\
\hline 20. & Oxacillin & $\leq 0.25$ & $>2$ & 2 & $\leq 0.25$ \\
\hline 21. & Penicillin & $\leq 0.03$ & $>8$ & $>8$ & $\leq 0.03$ \\
\hline 22. & Piperacillin/tazobactam & $\leq 4$ & $\leq 4$ & $\leq 4$ & $\leq 4$ \\
\hline 23. & Rifampin & $\leq 1$ & $>2$ & $>2$ & $\leq 1$ \\
\hline 24. & Synercid & $\leq 1$ & $>2$ & $>2$ & $\leq 1$ \\
\hline 25. & Tetracycline & $\leq 4$ & $\leq 4$ & 8 & $\leq 4$ \\
\hline 26. & Trimethoprim/sulfamethoxazole & $\leq 2 / 38$ & $>2 / 38$ & $\leq 2 / 38$ & $\leq 2 / 38$ \\
\hline 27. & Vancomycin & $\leq 2$ & $>16$ & $>16$ & $\leq 2$ \\
\hline
\end{tabular}

MIC values are presented in $\mu \mathrm{g} / \mathrm{mL}$; Gr.: Group

Table 1: Effect of biofield treatment on Streptococcus agalactiae group B to minimum inhibitory concentration (MIC) of tested antimicrobials. 


\begin{tabular}{|c|c|c|c|c|c|c|}
\hline \multirow[t]{3}{*}{ S. No. } & \multirow[t]{3}{*}{ Code } & \multirow[t]{3}{*}{ Biochemical } & \multirow[t]{3}{*}{ Gr. I } & \multicolumn{3}{|c|}{ Type of Response } \\
\hline & & & & \multicolumn{2}{|c|}{ Gr. II } & \multirow[t]{2}{*}{ Gr. III } \\
\hline & & & & Day 5 & Day 10 & \\
\hline 1. & ARA & Arabinose & - & - & - & - \\
\hline 2. & ARG & Arginine & + & + & - & + \\
\hline 3. & $\mathrm{BAC}$ & Bacillosamine & + & + & + & + \\
\hline 4. & $\mathrm{BE}$ & Bile esculin & - & + & + & - \\
\hline 5. & $\mathrm{BL}$ & Beta lactamases & NR & NR & NR & NR \\
\hline 6. & $\mathrm{CV}$ & Crystal violet & - & + & + & - \\
\hline 7. & HEM & Hemolysin & + & + & + & + \\
\hline 8. & IDX & Indoxyl phosphatase & + & + & + & + \\
\hline 9. & INU & Inulin & - & - & - & - \\
\hline 10. & LAC & Acidification lactose & + & + & + & + \\
\hline 11. & MAN & Mannitol & - & + & + & - \\
\hline 12. & MNS & Mannose & + & + & + & + \\
\hline 13. & MS & Micrococcus screen & + & + & + & + \\
\hline 14. & $\mathrm{NaCl}$ & Sodium chloride & - & + & + & - \\
\hline 15. & NIT & Nitrate & - & + & + & - \\
\hline 16. & NOV & Novobiocin & - & + & + & - \\
\hline 17. & OPT & Optochin & + & + & + & + \\
\hline 18. & PGR & Glycosidase $^{*}$ & + & + & - & + \\
\hline 19. & PGT & Glycosidases" & + & + & + & + \\
\hline 20. & $\mathrm{PHO}$ & Phosphatase & + & + & + & + \\
\hline 21. & PRV & Pyruvate & + & - & - & + \\
\hline 22. & PYR & Pyrolidonyl arylamidase & - & + & + & - \\
\hline 23. & RAF & Raffinose & - & + & - & - \\
\hline 24. & RBS & Rambose & + & - & - & + \\
\hline 25. & SOR & Sorbitol & - & + & - & - \\
\hline 26. & TFG & Thymidine free growth & + & + & + & + \\
\hline 27. & TRE & Acidification trehalose & + & + & + & + \\
\hline 28. & URE & Urea & - & + & + & - \\
\hline 29. & VP & Voges-Proskauer & + & + & + & + \\
\hline
\end{tabular}

'-' (negative); '+' (positive); Gr.: Group; NR: Not reported; *PGR: p-nitro phenyl $\beta$-D- glucuronide; \#PGT: p-nitro phenyl $\beta$-D-galactopyranoside.

Table 2: Effect of biofield treatment on Streptococcus agalactiae group B to the biochemical reaction pattern.

show any change in all the treated groups after biofield treatment as compared to the control.

\section{Identification of organism by biotype number}

The species (S. agalactiae gr. B) was identified based on variety of conventional biochemical characters and biotyping. Biotype number of particular organism was evaluated after interpreting the results of the biochemical reactions. The biotype number then led to the particular organism identification. In this experiment, biotyping was performed using automated systems. Results showed changes of biotype numbers in the biofield treated Gr. II (on day 5 and 10) and Gr. III (on day 10) without alteration of organism. Based on the biochemical data, biotype number was changed in treated Gr. II on day 5 (777777615, S. agalactiae group B) and on day 10 (757677405, S. agalactiae group B) with respect to the control (237147047) i.e. S. agalactiae group B (Table 3). Biotyping, covers the overall cellular pattern of enzymatic activities of any organism. GBS can be characterized based on analysis of biochemical properties with CAMP, Na-hippurate positive and esculin negative as key characters [25]. In this experiment, bile esculin also showed negative (-) reaction in control sample, that directly correlated with literature. This negative reaction of esculin was altered after biofield treatment in revived treated cells of GBS. It was indicated that biofield treatment has the ability to alter the biochemical pattern which may be due to change the enzymatic reaction. So, it is assumed that these changes of biotype number without alteration in organism may be due to change of metabolic and/or enzymatic reactions of GBS.

Biofield treatment may responsible for alteration in microorganism at genetic and/or enzymaticlevel, which probably act on receptor protein. While altering receptor protein, ligand-receptor/protein interactions may alter that could lead to different phenotypic characteristics [26]. Biofield treatment might induce a significant changes in revived strain of GBS and altered the MIC values, biochemical reactions, and ultimately change the biotype number of microorganism.

\section{Conclusion}

Altogether, the biofield treatment has significantly altered $70.37 \%$, (out of twenty-seven) the MIC values of tested antimicrobials against the strain of S. agalactiae gr. B. Norfloxacin was improved the MIC value by two-fold ( 8 to $\leq 4 \mu \mathrm{g} / \mathrm{mL}$ ) in Gr. II on day 10 after biofield energy treatment as compared to the control. Additionally, it also significantly (48.28\%) altered the biochemical reactions pattern of biofield energy treated strain of S. agalactiae gr. B. On the basis of utilization of group B streptococcal specific biochemicals, change in metabolic reactions led to variation of biotype number in all the treated groups without change of organism after biofield treatment with respect to the control. Based on above findings, it is assumed that Mr. Trivedi's biofield treatment is 
Citation: Trivedi MK, Branton A, Trivedi D, Nayak G, Shettigar H, et al. (2015) Effect of Biofield Energy Treatment on Streptococcus group B: A Postpartum Pathogen. J Microb Biochem Technol 7: 269-273. doi:10.4172/1948-5948.1000223

\begin{tabular}{|c|c|c|c|c|}
\hline Feature & Gr. I & Gr. III & Gr. II \\
\cline { 3 - 4 } & Day 10 & Day 10 & 757677405 \\
\hline Biotype & 237147047 & 777777615 & 237147047 \\
\hline Organism Identification & Streptococcus agalactiae group B & $\begin{array}{c}\text { Streptococcus agalactiae group B } \\
\text { (Very rare biotype) }\end{array}$ & $\begin{array}{c}\text { Streptococcus agalactiae group B } \\
\text { (Very rare biotype) }\end{array}$ & $\begin{array}{c}\text { Streptococcus agalactiae group B } \\
\text { (Very }\end{array}$ \\
\hline
\end{tabular}

Gr.: Group

Table 3: Effect of biofield treatment on biotype number of Streptococcus agalactiae group B.

an alternative approach to alter the antibiogram profile of $S$. agalactiae gr. B.

\section{Acknowledgement}

Authors gratefully acknowledged to Trivedi science, Trivedi testimonials and Trivedi master wellness and the whole team of PD Hinduja National Hospital and MRC, Mumbai, Microbiology Lab for their support.

\section{References}

1. Campbell JR, Hillier SL, Krohn MA, Ferrieri P, Zaleznik DF, et al. (2000) Group B Streptococcal colonization and serotype-specific immunity in pregnant women at delivery. Obstet Gynecol 96: 498-503.

2. Cowgill K, Taylor TH Jr, Schuchat A, Schrag S (2003) Report from the CDC. Awareness of perinatal group B streptococcal infection among women of childbearing age in the United States, 1999 and 2002. J Womens Health (Larchmt) 12: 527-532.

3. Mullaney DM (2001) Group B streptococcal infections in newborns. J Obstet Gynecol Neonatal Nurs 30: 649-658.

4. van der Poll T, Opal SM (2008) Host-pathogen interactions in sepsis. Lancet Infect Dis 8: 32-43.

5. Ratner HB, Weeks LS, Stratton CW (1986) Evaluation of spot CAMP test for identification of group B streptococci. J Clin Microbiol 24: 296-297.

6. Schuchat A, Wenger JD (1994) Epidemiology of group B streptococcal disease. Risk factors, prevention strategies, and vaccine development. Epidemiol Rev 16: $374-402$.

7. Jacobs MR, Kelly F, Speck WT (1982) Susceptibility of group B streptococci to 16 beta-lactam antibiotics, including new penicillin and cephalosporin derivatives. Antimicrob Agents Chemother 22: 897-900.

8. McCracken GH Jr, Ginsberg C, Chrane DF, Thomas ML, Horton LJ (1973) Clinical pharmacology of penicillin in newborn infants. J Pediatr 82: 692-698.

9. Myers R (2003) The basics of chemistry. Greenwood Press, Westport, Connecticut.

10. Movaffaghi Z, Farsi M (2009) Biofield therapies: biophysical basis and biological regulations? Complement Ther Clin Pract 15: 35-37.

11. Rivera-Ruiz M, Cajavilca C, Varon J (2008) Einthoven's string galvanometer: the first electrocardiograph. Tex Heart Inst J 35: 174-178.

12. Trivedi MK, Tallapragada RM (2008) A transcendental to changing metal powder characteristics. Met Powder Rep 63: 22-28, 31.

13. Trivedi MK, Nayak G, Patil S, Tallapragada RM, Latiyal O (2015) Studies of the atomic and crystalline characteristics of ceramic oxide nano powders after Biofield treatment. Ind Eng Manage 4: 161.

14. Dabhade VV, Tallapragada RR, Trivedi MK (2009) Effect of external energy on atomic, crystalline and powder characteristics of antimony and bismuth powders. Bull Mater Sci 32: 471-479.

15. Sances F, Flora E, Patil S, Spence A, Shinde V (2013) Impact of biofield treatment on ginseng and organic blueberry yield. Agrivita J Agric Sci 35: 22-29.

16. Lenssen AW (2013) Biofield and fungicide seed treatment influences on soybean productivity, seed quality and weed community. Agricultural Journal 83: $138-143$

17. Trivedi MK, Patil S, Shettigar H, Gangwar M, Jana S (2015) Antimicrobial sensitivity pattern of $P$ seudomonas fluorescens after biofield treatment. J Infect Dis Ther 3: 222

18. Trivedi MK, Patil S, Shettigar H, Bairwa K, Jana S (2015) Phenotypic and biotypic characterization of Klebsiella oxytoca: An impact of biofield treatment. J Microb Biochem Technol 7: 203-206.

19. Trivedi MK, Patil S, Shettigar H, Gangwar M, Jana S (2015) An effect of biofield treatment on multidrug-resistant Burkholderia cepacia: A multihost pathogen. J Trop Dis 3: 167.

20. Patil SA, Nayak GB, Barve SS, Tembe RP, Khan RR (2012) Impact of biofield treatment on growth and anatomical characteristics of Pogostemon cablin (Benth.). Biotechnology 11: 154-162.

21. Nayak G, Altekar N (2015) Effect of biofield treatment on plant growth and adaptation. J Environ Health Sci 1: 1-9.

22. Fader RC, Weaver E, Fossett R, Toyras M, Vanderlaan J, et al. (2013) Multilaboratory study of the biomic automated well-reading instrument versus MicroScan WalkAway for reading MicroScan antimicrobial susceptibility and identification panels. J Clin Microbiol 51: 1548-1554.

23. Kaufhold A, Ferrieri $P$ (1993) The microbiologic aspects, including diagnosis, of beta-hemolytic streptococcal and enterococcal infections. Infect Dis Clin North Am 7: 235-256.

24. Facklam RR, Thacker LG, Fox B, Eriquez L (1982) Presumptive identification of streptococci with a new test system. J Clin Microbiol 15: 987-990.

25. Ekin IH, Gurturk K, Yaman G, Yesilova A (2010) Biotyping of nontypeable Group B Streptococci. Van Vet J 21: 117-122.

26. Lindstrom E, Mild KH, Lundgren E (1998) Analysis of the T cell activation signaling pathway during ELF magnetic field exposure, p56 lck and $\left[\mathrm{Ca}^{2+}\right]$ i-measurements. Bioeletrochem Bioenerg 46: 129-137. 